\title{
Discourses of the Good Parent in Attributing School Success
}

Sue Thomas, Jayne Keogh and Steve Hay

Griffith University

\begin{abstract}
Recent education policy places a heavy emphasis on parents in relation to students' success at school. This paper explores how parents and teachers account for school success.

Drawing on resources from Membership Categorisation Analysis (MCA), it interrogates data collected in different interview situations across sites over a period of twenty years. The analysis shows how parents and teachers use talk as moral work to conversationally constitute particular agreed versions of the category "parent". This category is interactively assembled through the use of category-bound attributes that construct deficit discourses of parents that explain student achievement. The analysis demonstrates that parents are complicit with teachers in producing versions of being a good parent wherein they are held responsible for their children's school success and that minimises the responsibility of the school. These findings raise questions about who is responsible for schooling and current contradictory policy emphases on parent and teacher responsibility for school success.
\end{abstract}

Key Words: Discourse; Membership Categorisation Analysis; education policy; parents; school success; teacher quality 


\section{Authors' biographical notes}

Sue Thomas is an Associate Professor in Education at Griffith University, Australia. Her research investigates the interrelationships between education policy and other institutions, such as the media, schooling practices and professional identities. Current research focuses on the enactment of policies as teachers and school leaders recontextualise policy in local sites.

Correspondence to Associate Professor Sue Thomas, School of Education \& Professional Studies, Griffith University (Mt Gravatt), Australia,Email: s.thomas@griffith.edu.au

Jayne Keogh is a teacher educator at Griffith University, Queensland, Australia, lecturing in the middle years of schooling and educational theory into practice. She is a qualitative researcher whose interests focus on the interactive co-construction of education-based institutional arrangements, including parent-teacher relationships, induction into the teaching profession, and beginning teacher experiences.

Correspondence to Dr Jayne Keogh, School of Education and Professional Studies, Griffith University (Gold Coast), Parklands Drive, Southport, 4222,

Australia.Email:j.keogh@griffith.edu.au

Stephen Hay is Senior Lecturer in Education at Griffith University, Queensland, Australia. His research interests are in education policy in terms of educational governance, globalisation and social justice. Current research investigates how social and educational governance in Australia is realised through social spaces linking schools to industry-school partnerships.

Correspondence to Stephen Hay, Griffith University, School of Education and Professional Studies (Mt Gravatt Campus) Griffith University, 4111, Australia. E-mail: s.hay@griffith.edu.au. 


\section{Introduction}

Education policy sees school success as a collective responsibility that schools share with students, parents, carers and families (Ministerial Council on Education Employment Training and Youth Affairs 2008). For example, in South East Queensland, where this study is conducted, a recent government document states that while schools and teachers make a crucial difference to children's school results, the influence of parents and families still has the greatest effect. The more children learn at home before they start school, the better equipped they are to make the successful transition to school. The more parents support their children by being involved in their education, the more they cultivate their child's love of learning and their chances to succeed. Research shows that children whose families encourage reading at home do better at school, and that parents' and carers' ongoing involvement in their child's schooling through helping with homework and other learning activities is essential for children's success (Queensland Government, 2010, p. 2).

This document was referring to young children beginning school, but similar sentiments are found in policies relating to planning for students' transitions from secondary school to postschool life (The State of Queensland, 2010). As Gewirtz (2001) notes, policy makers, cognizant of research pointing to the impact of home environments on educational outcomes, have sought to redress educational inequalities by attempting to transform the behaviours of parents. Gewirtz (2001) argues that these strategies aim to make the "many behave like the few" by universalising "the values, attitudes and behaviours of a certain fraction of middle class parents" (p. 366). She points to policy fabrications of the ideal parent whose behaviours might be adopted or simulated by all parents.

In addition, research studies have long identified parents and families as crucial indicators of success in schooling (cf. Bowles \& Gintis, 1976, for an example of early 
studies). These studies have resulted in a heavy emphasis being placed on the relationship between family social class and school success. More recently, while the importance of family social class continues to be acknowledged, the ways in which race, gender and social class shape parental strategies that are influential to school success having become the focus of several studies (cf. Bodovski, 2010; Siraj-Blatchford, 2010; Vincent, Ball, \& Braun, 2010). That is, while family social class impacts on children's educational attainments, they are influenced also by the children's own educational and occupational aspirations, peer influences and the encouragement of parents (Bodovski, 2010). Consequently, parents are increasingly being assailed by disparate discourses constructing different versions of "good" and "necessary" parenting (Vincent and Ball, 2007).

This paper explores constructions of the good parent. It draws on key resources derived from Membership Categorisation Analysis (MCA) (Heritage 1984; Sacks 1992) to interrogate data collected in different interview situations across over a period of twenty years. Analysis shows how the speakers, specifically teachers and parents, construct parent as a moral category, making parents responsible for their children's school success. First, the paper discusses the idea, drawn from MCA, of talk as moral organisational work (Jayyusi, $1984 \&$ 1991). Next, it outlines the framework adopted for the analysis of categories of parent and gives details of the studies in which these accounts are situated. The paper then analyses the data in terms of the ways in which different data sets reveal how versions of parents are discursively constructed. The analysis is then interrogated to identify discourses on parenting and school success in the Australian context across twenty years.

\section{Talk as moral organisational work}

Membership categorisation analysts understand the world as interactively achieved through the process of categorisation as meaning-making work. It is through the process of categorisation that members of society conversationally constitute categorical groups 
(collections) to make sense of their co-constructed and assumed-to-be shared worlds (Sacks 1992). Speakers actively assemble and naturalise particular versions of the social world that are occasioned within the talk itself. They constitute categories by producing, orienting to and making relevant particular categorical memberships, positioning themselves and holding each other accountable for their practices as members of particular category collections. So it is that speakers talk with each other as members of particular categories, about members of different categories.

Members use membership categorisation devices (MCDs), locally and situationally, for particular practical purposes. MCDs can be likened to "inference-making machines" (cf. Sacks, 1992, 113-125) that conversationally assemble different categories as members of particular categorical collections. These categories are produced as standardised relational pairs (SRPs) that tend to be articulated within identifiable parameters of normativity, deriving their meaning from the speakers' co-constituted commonsense and assumed-to-be shared knowledges (Housley \& Fitzgerald, 2002). Category-bound attributions are situationally assembled by ascribing associated actions, rights, responsibilities and obligations that are exclusive to the membership of each SRP category. Members of each category pair are invoked as relatively good or bad in relation to moral attributions that are accomplished "not only with respect to persons ... [but] may also be used in respect of collectivities" (Hester \& Hester, 2012, p. 5). As such, talking the world into being through conversational categorisation work is, through and through, a morally implicative process (Jayyusi, 1984, 1991). Use of strategies pertaining to MCA can, thus, reveal the complex ways in which moral versions of different categories are interactively assembled to talk the world into-being (Heritage, 1984) as culture in action (Baker, 2000). 


\section{Research method}

This paper focuses on extracts of talk between teachers and parents to show the ways in which the speakers produce particular versions of parenting and school success, conversationally locking these discourses into place. Analysis reveals how the speakers' interactively achieve versions of what social actors do, could or should behave, and how acceptable versus unacceptable courses of social action are implied.

Using a framework adapted from Baker (2000), the analytic process follows four stages. First, the data are examined to locate the central categories and collections of people, and their category-bound attributions. Second, standardised relational categorical pairs are classified within a conversationally assembled moral order. Third, category-bound attributions and activities are identified to document the morally implicative ways that the speakers conversationally assemble their versions of "good" versus "not so good parent". Having worked through each extract, the final analytic stage was that of looking for and identifying any recurring assemblages or patterns in the machinery of the talk that produced versions of the overall institutional social and moral order in the form of discourses of parents and parenting. It is these versions of the world that are of interest in that the discourses revealed in these instances of talk locked particular categorical constructions of the participants' versions of their institutional worlds into place.

\section{The data}

The interview data used for this paper was collected in two separate and unrelated projects that were conducted by the authors over the past two decades. One data set that included parent-teacher interview talk was collected for postgraduate research projects (see Keogh, 1992, 1999) examining the discursive construction of home-school relations. The first two extracts (extracts 1 and 2) were produced at two different secondary schools - one a state school and one a private school. The second set of data (extracts 3, 4 and 5) was collected as 
part of an ARC Discovery project ${ }^{1}$ investigating students', teachers' and parents' experiences of programs designed to manage students' school to work transitions in four south-east Queensland church affiliated secondary schools (see Billett, Thomas, Sim, Johnson, Hay \& Ryan, 2010; Thomas \& Hay, 2012). The data set from this project used for this paper was taken from a parent focus group interview. The focus group involved parents whose children attended the participating school and who were all members of the school Board. All interview data were audio-recorded and later transcribed. An explanation of the transcription conventions is found in Appendix 1. Extracts that focused on characteristics of parenting were chosen for closer analysis.

\section{Analysis and findings}

\section{Co-constructing parents as moral categories}

In the following two extracts of talk taken from parent-teacher interviews, the participants co-constructed parental work in relation to responsibilities for knowing about and supervising their children's school-associated study habits in their homes. Extract 1 took place at an official school parent-teacher interview night at an independent private school. The student, Shirley ${ }^{2}$, was not present at this meeting.

\section{Extract 1}

Teacher: $(T)$

\section{Parent: (F) Father}

1. T. ... I'm, wondering if you can tell me if there've been any (0.5) sort of things

2. upsetting her? that would prevent her from studying?

3. F. erm not that I know of she's got she's got her own room and [she's got

\footnotetext{
${ }^{1}$ The authors acknowledge the support provided by the Australian Research Council Discovery Projects scheme to undertake the research reported here.

${ }^{2}$ For the purposes of confidentiality, the names of all participants in these interviews are pseudonyms
} 
5. F. (0.5) ah everything she want the only thing that's er, the latest addition is erm,

6. radio cassette, so whether or not that's (0.5) that's interfered?

7. T. right (I'm)

8. F. um (0.5) she hasn't had access to TV during the week an' (2.0) this sort of ah

9. th' policy being the TV goes on in the weekend not during the week

10. T. right

11. F. ah don't sort of push the kids to study but they have the environment

12. $\quad$ [in which

13. T. $[\mathrm{mm}$

14. F. study and it's [their choice

15. $T$

[mm mm now in class it seems very clear that she

16. does homework

Extract 1 took place about one third of the way into this parent teacher meeting. In their talk, the father and the teacher can be seen to be orienting to their respective categorical memberships, with particular rights. So, for example, in her first turn, the teacher asks the father about his practices, demonstrating her institutional right to set up the matter at hand (that of his daughter's study habits), and the father seems to concur with this associated right. Father and his daughter are set up as members of a categorical standardised relational pair (SRP), situated as members of the collection home. They are talked-into-being in terms of their respective category-bound attributions, the teacher holding the father's parenting practices accountable within a particular moral order.

The teacher first asks the father about his knowledge of daughter's emotional state: "I'm, wondering if you can tell me if there've been any (0.5) sort of things 
upsetting her? that would prevent her from studying?". By introducing the categorybound parental attribution of knowing about his daughter's emotional wellbeing and for study habits, the teacher assembles a moral version of "father" by holding him responsible accountable for these activities. It is noteworthy that the teacher speaks of studying, an activity more usually associated with school than with home, making a school discourse relevant to home practices.

The father's reply, "erm not that I know of" shows acceptance of his parental responsibilities, although his slight erm signals that his acknowledged lack of knowledge may have been heard by the teacher as possibly deficient. However, in lines 3 to 6 , the father deflects this possibly by making his daughter, rather than himself, responsible for her work habits when he says "she's [Shirley's] got she's got her own room and she's got ... ah everything she want", thereby rebutting potential criticism of his possibly inadequate parental practices.

The father's use of erm in line 5 again suggests potential parental inadequacy, when he suggests that provision of a radio cassette and TV may, perhaps, be interfering with his daughter's studying. However, he then counters such a hearing by saying that he prohibited "access to TV during the week" (line 8), emphasising that "the TV [only] goes on in the weekend [and] not during the wee" (lines 9 to 10). Furthermore, he says that he "does not push the kids" (line 11) but, rather, provides a study-conducive environment, producing a version of himself as a "good" parent who allows his children to take responsibility for managing their own study habits. That the teacher accepts this moral version of the father is confirmed in lines 15 to 16 ("mm mm"), signalling agreement by saying that "in class it seems very clear that she [Shirley] does homework".

In this extract the teacher holds this father accountable for his parenting practices, a responsibility that he accepts. Although the father initially suggests that his practices 
may be heard as deficit, he rebuts this possibility by making his daughter rather than himself responsible for her study, thereby maintaining a version of himself as a "good parent". The teacher confirms this in her final response here. So it is that this home is set up within a particular moral order that requires the parent to know about and manage his daughter's study. Both speakers orient to a normalised and assumed-to-be-shared commonsense understanding about what it is to be a "good parent". Support for successful student learning is, thus, made a category-bound attribution exclusive to parents rather than to teachers, and the matter of the school's (teacher's) work in this process is not raised.

In extract 2 (below), the student, Jessica, attends and participates in the talk with her mother and teacher. This meeting took place at a parent-teacher interview night at a state secondary school. The collection is home and the speakers here work together to coconstruct the categories student, parent and teacher, orienting to and making relevant a particular moral order. The extract begins with the teacher talking to Jessica, as direct recipient, when she raises the topic of Jessica's homework undertaken at home:

\section{Extract 2:}

Teacher: $(T)$

\section{Student: (S) Jessica}

\section{Parent: (M) Mother}

1. T. Right. It's okay. Do you write at home much? Apart from the work you

2. have to do um, at home? Apart from homework. Do you do any writing,

3. at all?

4. S. Yeah

5. T. Do you write letters? 
6. S. Yeah

7. T. Right. I see, um do you watch a l:ot of TV?

8. S. Yeah

9. T. You do. Do you do a lot of c-of oral

10. M. Not really none of us really watches a lot of TV( ) [a bit

11. $T$. [oh yeah

12. [we all do

13. M. [a bit doesn't hurt

It is notable that writing is an activity that is, perhaps, more usually associated with the classroom rather than with home space. This talk, thus, conversationally colonises the home, subsuming it within a dominant school-related discourse. As in extract 1 (above), the issue of the teacher's role in facilitating Jessica's writing is not raised in this extract.

The teacher sets up the activity writing in the form of a standardised relational pair, contrasting "the work you have to do ... at home?" with homework. In this way she constructs the category-bound attribution of "writing" with the category "student", setting up a moral order in her implication that writing is what a "good" student should do at home. Jessica responds positively in lines 4 and 6, and the teacher seems to agree. However, when Jessica says "yeah" in line 8, in response to the teacher's question about watching "a lot of TV" (line 7), although the teacher does not make this a problem, moving on to another topic (Jessica's oral), the mother interrupts their dialogue in line 10. It seems that the mother has oriented to earlier talk about watching TV, hearing it as implying criticism of her parenting practices. She pre-empts and rebuts this possibility in lines 10 ("none of us really watches a lot of TV"), and 13 ("a bit doesn’t hurt"), 
positioning herself as a member of the category "parent" who is responsible for knowing about and controlling the amount of television watched at home. In taking up the lead in this talk, the mother positions herself and her daughter within the collection family, situating themselves at home where TV is viewed, conversationally excluding the teacher from that home space. Rather than questioning this further, the teacher agrees with the construction, re-aligning herself with the mother and confirming her as a "good" parent when she normalises and makes acceptable the activity of viewing television when she says "oh yeah we all do" (lines 11 and 12). The mother shows agreement in line 13 when she draws this topic to a close by saying, "a bit doesn't hurt". It is noteworthy that in lines 11 and 12 the teacher, by using the collective pronoun "we", seems to be speaking as a parent rather than as a teacher, an MCD that re-aligning herself with the mother within a shared moral order that requires a "good" parent to manage homework.

Talk in both extracts focussed particularly on matters of parental accountability. The parents were constituted as "good" parents who know about, care for, and supervise/control their children's school work at home. Assemblages of "good" and "not so good parents" were co-constructed within both extracts. A parental category-bound attribution was that of continuing the work of the school at home. The parents oriented to and agreed with this positioning, rebutting versions of themselves as possibly "not so good parents", thus maintaining acceptable versions of themselves and their practices as "good parents". In such ways, matters of parental responsibility were made morally implicative. The role of the teacher, as a member of the collection "school", was neither acknowledged nor made accountable in these two extracts.

\section{Assembling moral versions of the parent as helpful coach}

The paper now turns to a discussion of how parents assembled versions of "good parents" in a parent focus group interview. The interview explored parents' experiences during their 
children's transition through the final years of secondary schooling to post-school life. As noted above, the parents were all members of the school board of a church-affiliated secondary school. As such, it is not surprising that they would favour involvement in their children's schooling. Nevertheless, an analysis of their talk traces particular versions of a good parent and what this group should do to ensure school success. It should be noted here, that the parents talked about children or kids, rather than students. Such terminology is significant because, as will be seen through the following extracts, the parent saw school success as being a matter for the family. Initial talk in the interview began with the construction of versions of the good and not so good parent.

\section{Extract 3}

\section{Interviewer: I}

\section{Parent: P}

1. I. Do you as parents feel that you have had sufficient opportunities

2. $\quad$ to influence the school and the school's plan and how the school

3. plans and conducts the transition program?

4. P4. I believe those avenues exist in most schools, but I think not all

5. parents necessarily know how to exercise the involvement that

6. they can have in schools now. It's a cultural change from one

7. era where schools were responding to knowledge, or you know,

8. $\quad$ to influence and now we are talking about community

9. participation and parent involvement and parent input and,

10. you know, join decision making and all that, which is all good. I think

11. it's just going to take time for parents to truly understand what that

12. means and even the school, the leadership of the school but it's 
13. valuable that's where things are going, but that will take time to grow.

14. Some parents have had school experiences where you shut up and do

15. as you're told and I mean we have to go in there and talk and be

16. listened to and share our and table some ideas, you know.

In this extract, versions of the category "parent" are constructed in terms of the attribution of involvement with the school. The talk constructs versions of the "good parent" and the "not so good parent". Good parents are described as being involved in their children's schooling. They know and understand the ways to be involved in schools and actively participate by sharing ideas and making sure that these ideas are listened to (lines 5-12). Not so good parents, on the other hand, neither know nor understand the possibilities of involvement in their children's schooling. Rather they "shut up" (line 14) and do as they are told.

Having established what not so good parents are and do, the focus of the talk switched to the construction of a collection, the family, and to the establishment of the importance of the family to a successful transition through schooling to post-school life. As Extract 4 shows, the family is constituted through the standard relational pair of "parent" and "children".

\section{Extract 4}

\section{Interviewer: I}

\section{Parents: P 1-3}

1. I. What do you do to help your child make this transition through Years

2. $10,11,12$ and then to work?

3. P1. I would say I just, for example, my daughter likes watching The Bill.

4. And so we watch The Bill and talk about what her future is going to be

5. like and what she would like to specialise in. She says she wants to be 
6. teacher. That worries me because I think she is just doing the family thing but

7. I don't want her to do that. I want to encourage her to really trying to look at

8. those other avenues and you know, think about something different, because

9. it's almost like she doesn't know - I don't know whether your kids are like

10. that [parent's name]?

11. P2. I think you just have to keep talking to them and keep exposing them to

12. as much as you can, you know.

13. P3. Yeah.

14. P2. I mean we take our kids to the Career Expo...

15. P3. Exactly and everything in the newsletters...

16. P2. You have got to go through the situations vacant and just talk about

17. what they want to do. Because I mean you know, I still don't know

18. what I want to do when I grow up.

In this extract, parents are associated with the attributions of help and encouragement. The attribution associated with children is making the transition to post-school life. Good parents are constructed as helping their children to make this transition. They do so by doing things together, such as watching TV with their children. They use these times to discuss possibilities for the child's future and to encourage their children to look at different options (lines 3-8). Later in the interview, this activity is described as "finding a common ground". Good parents need to do this work because their children do not know what they want to do or even what the possibilities are (line 9).

The category of parent is developed further as the interview progresses. The talk adds a new dimension to the attributions associated with parents, that of nurturing. Good parents nurture their children in order to help them to gain well-paid employment, usually through 
academic "training" although success at schooling is not considered to be essential. Rather, as the next extract shows, the attribution associated with both parents and children is having a work ethic. The extract uses the collection of family to construct the standard relational pairs of good parent and not so good parent, and good children and not so good children.

\section{Extract 5}

\section{Interviewer: I}

\section{Parents: P 1-5}

1. P1. It's very hard to educate someone to a work ethic

2. P2. But I think most children look to their parents for that.

3. If the parents don't have a work ethic, then the child doesn't.

4. $\quad$ And to me we are getting into a whole different area about the family

5. unit, which we don't really have much of a family unit these days with

6. $50 \%$ divorces. So it really comes down to the fact of what Mum and

7. Dad did or Uncle or Aunt or whatever the case may be and the way that

8. $\quad$ they treat work and value it

15. And that's why this work ethic is extremely important and it's not

16. written in a book and I don't think it is actually anything that you can

17. actually teach on a blackboard, it's something that the children learn

18. from their parents.

19. P3. It's expectations. For example for the first car, some parents say you work for

20. 12 or 18 months and some parent will pay the rego and insurance and other

21. ones, they will meet you half way, but all those things teach you along the road

22. that you should value what you get. But it's true, it's handed down. 
23. P4. But it's the issue of age as well, because when you are going through

24. $\quad$ this transition it's the most likely time in your life to have a bad

25. attitude generally and they are going through a rebellious stages and all

26. that jazz. And as you say, you talk about the family unit. There is a

27. tendency I think for people to say, "I don't give my children enough

28. time, so I will give them stuff instead." And then they get their first car,

29. given to them on their $18^{\text {th }}$ birthday. And I don't know what the answer

30. is, but that doesn't create an expectation that I have to do anything to

31. get something.

32. P5. I think that the other thing is that as a parent you have only got your

33. $\quad$ own upbringing to use as a guide.

The attributions of work, ethics and values are associated with all four categories constituted in the talk. Good parents are depicted as valuing work and instilling a work ethic in their children. They do this by teaching their children to value what they get, for example, paid car registration; by creating an expectation that children have to do things to get something; and by using their upbringing as guide. In contrast, not so good parents don't give children enough time and give them stuff instead, such as a car on the child's eighteenth birthday. These examples illustrate how parental activities work to ensure that children have the necessary values to succeed. In all instances of talk, the parents construct a moral version of the good parent that is associated with encouragement, helping and directing. As one parent says, "we should be coaching and directing our children". Explicit in the talk is the construction of parents as the guide and director and children as the receivers of this guidance. Importantly, they are interventionists who coach and direct their children as they transition through secondary schooling to post-school life. Children are positioned as being dependent 
on their parents for guidance and direction. The parents present themselves publicly in a positive way and children are positioned as being in need of parental direction, that is, in a dependent, deficit way.

\section{Discussion}

The above analysis has shown how the teachers and parents constructed moral versions of parenting through interview talk. Analysis has shown how the talk produced moral versions of parents and constructed, or locked into place particular discourses of parenting. Further it showed that these same discourses on parenting were constructed over the twenty-year period of data collection. Within the five examples of talk about parenting practices, versions of good versus not so good parents were talked into being in terms of who took responsibility for children's/students' school success, whether it be successful homework and study habits (extracts 1 and 2), or transitions from school into the world of work (extracts 5 to 7). In all five extracts of talk with and about parents, "good" versus "not so good" parents were conversationally assembled as having similar attributions, the talk producing common sense taken-for-granted versions of what such parents should be and do, actively assembling parent roles and responsibilities within a moral social order.

In extracts 1 and 2, teachers, students and parents talked together, conversationally coconstructing complex versions of good versus not so good parents. Parent categories were assembled in terms of whether and how well parents were able to enact their parental responsibilities in continuing the work of the school and facilitating their children's/students' success within their homes. Parenting practices were made accountable actions, the parents presenting themselves overall as mostly good parents who had the skills to take on their coconstructed responsibilities effectively. Within these extracts the teachers conversationally implied and made these parents' practices morally implicative, but accepted and confirmed these parent's versions of themselves as "good" rather than "not so good parents". However, 
the work of the teachers in facilitating student learning is not acknowledged in either extract. As such, the membership categorisation devices used by the speakers positioned the parents, alone, as responsible for student success, simultaneously abrogating the involvement of the teacher or the school in taking responsibility in this activity.

Similarly, in extracts 3, 4 and 5, the parents themselves took full responsibility for their parenting practices in relation to supporting post school student transitions. "Good" versus "not so good" parental categories were talked into being in terms of how well or otherwise parents were able to take up these responsibilities. The parents positioned and constructed themselves as good parents who had effective attributions that would support their children's future success. However, they simultaneously and explicitly talked into being other not so good parents who were not able to support such transitional success, providing reasons for their relative lack of success. These parents constituted themselves as ideal typical models of involved and supportive parents through reference to certain kinds of entrepreneurial behaviour. Importantly, they held themselves, rather than the school, responsible for the educational success of their children.

The interview talk constructed discourses of the good parent that attributed responsibility for school success to parents. Through this discursive translation, the school was absolved of its responsibility for ensuring successful transition outcomes for students. That is, the extracts provide insight into dominant discourses of parenting that have emerged within education policy in recent years. These discourses have tended increasingly to hold parents responsible for the educational outcomes of students and have sought to shift responsibility for student's educational outcomes away from education bureaucracies and schools and onto parents and students themselves.

At the same time, however, policy discourses have focused on teacher quality (Education Queensland 2009, Council of Australian Governments, 2009). The Australian 
Department of Education website states that "it has long been recognised that teacher quality is the single most important factor, in a school, in influencing student engagement and achievement" (Department of Education 2013). Further, quality teaching discourses have depicted teachers in a deficit way, as needing improvement if Australian schools are to be successful (Thomas, 2011; Thomas \& Watson, 2011). That is, policy discourses on quality teaching attribute primary responsibility for school success, or rather failure, to teachers. This statement is at odds with the collective reponsibility emphasised in the Melbourne Declaration (2008). Such apparently contradictory discourses are not surprising, given the plethora of multiple and contradictory policies noted by Braun, Maguire and Ball (2010). However, there is a common feature in both sets of policy discourses in that they both attribute responsibility for school success to individual parents and teachers as members and in so doing absolve education bureaucracies and the schooling system from such responsibility.

\section{Conclusion}

This paper used resources drawn from MCA to analyse sets of data collected across twenty years in order to identify the discourses of the "good parent" constructed by teachers and parents and, in so doing, demonstrated how such discourses attributed school success to particular moral versions of being a parent. The analysis revealed commonalities across time in that parents are categorised consistently as being responsible for students' lack of achievement. Further, the analysis showed how such categorisations serve to construct discourses of parents to account for success, or the lack of success, at school. Such discourses constructed shared descriptions and expectations regarding what parents are and should be, and what they should be responsible for. The analysis of data across the twenty-year period show that dominant discourses related to responsible parenting remain powerful and persistent partly because of their ready translatability across educational contexts (e.g., policy 
formulation, teacher talk, parent self-identity). At the same time, discourses of quality attribute responsibility for school success to teachers. The presence of both discourses raise questions about the nature of, and who is responsible for, student success in contemporary schooling. 


\section{References}

Atkinson, J.M. \& Heritage, J. (Eds.). (1984). Structures of social action. Cambridge, UK: Cambridge University Press.

Baker, C. (2000). Locating culture in action: membership catgorisation in texts and talk. In A. Lee \& C. Poynton (Eds.), Culture and Text (pp. 99-113). St Leonards, NSW: Allen \& Unwin.

Billett, S., Thomas, S., Sim, C., Johnson, G., Hay, S., \& Ryan, J. (2010). Constructing productive post-school transitions: An analysis of Australian schooling policies. Journal of Education and Work, 23(5), 471-489. doi: 10.1080/13639080.2010.526596

Bodovski, K. (2010). Parental practices and educational achievement: social class, race and habitus. British Journal of Sociology of Education, 31(2), 139-156.

Bowles, S. \& Gintis, H. (1976) Schooling in Capitalist America: Education Reform and the Contradictions of Economic Life. New York: Basic Books.

Braun, A., Maguire, M., \& Ball, S. J. (2010). Policy enactment in the UK secondary school: examining policy, practice and school positioning. Journal of Education Policy, 25(4), 547-560. doi: 10.1080/02680931003698544

Council of Australian Governments (2009b) National Partnership Agreement on improving teacher quality. Council of Australian Governments. Retrieved from http://www.coag.gov.au/intergov_agreements/federal_financial_relations/index.cfm

Department of Education (2013) Quality Teaching. Australian Government. Retrieved from http://www.education.gov.au/quality-teaching.

Education Queensland (2009). Smarter Schools National Partnerships. Retrieved from http://www.education.qld.gov.au/nationalpartnerships

Gewirtz, S. (2001). Cloning the Blairs: New Labour's programme for the re-socialization of working-class parents. Journal of Education Policy, 16(4), 365-378.

Heritage, J. (1984). Garfinkel and Ethnomethodology. Cambridge: Polity Press. 
Hester, S. \& Hester, S. (2012). Categorial occasionality and transformation: Analyzing culture in action. Human Studies. (Published on line, 8 March 2012. Retrieved from http://www.springerlink.com.libraryproxy.griffith.edu.au/content/j0uv135304433452/fu lltext.pdf

Housley, W. \& Fitzgerald, R. (2002). The reconsidered model of membership categorization analysis. Qualitative Analysis 2(1), 59 - 82.

Jayyusi, L. (1984). Categorization and the moral order. Boston: Routledge \& Kegan Paul.

Jayyusi, L. (1991). Values and moral judgement: communicative praxis as a moral order. In G. Button (Ed.), Ethnomethodology and the human sciences (pp. 227-251). Cambridge: Cambridge University Press.

Keogh, J. (1992). Identity, Ideology and Power: A Study of Parent-Teacher Interviews. Unpublished Masters Thesis. University of New England, NSW.

Keogh, J. (1999). The Role of Texts and Talk in Mediating Relations between Home and School. Unpublished Doctoral Thesis. Griffith University, Qld.

Ministerial Council on Education, Employment, Training and Youth Affairs (2008). Melbourne Declaration on Educational Goals for Young Australians. Retrieved from www.mceecdya.edu.au/verve/_resources/National_Declaration_on_the_Educational_G oals_for_Young_Australians.pdf

Sacks, H. (1992). Lectures in conversation, Volumes 1 \& 2. G. Jefferson (Ed.). Oxford: Basil Blackwell.

Sacks, H. (1984). Notes on methodology. In J.M. Atkinson \& J. Heritage (Eds.). Structures of social action: Studies in conversation analysis. Cambridge: Cambridge University Press.

Siraj-Blatchford, I. (2010). Learning in the home and at school: how working class children "succeed against the odds"،. British Educational Research Journal, 36(3), 463-482. 
The State of Queensland. (2010). SET Plans A Guide for Administrators of Schools and Leaders. Spring Hill: Queensland Studies Authority.

Thomas, S. (2011). Teachers and Public Engagement: an argument for rethinking teacher professionalism to challenge deficit discourses in the public sphere. Discourse: Studies in the Cultural Politics of Education, 23(3), 371-382.

Thomas, S. \& Hay, S. (2012). Governing Schooling, People and Practices: Australian Policies on Transitions. In Billett, S., Johnson, G., Thomas, S., Sim, C., Hay, S. \& Ryan, J. (Eds.) (2012). Experiences of school transitions: Policies, practices and participants. Dordrecht, The Netherlands: Springer.

Thomas, S. \& Watson, L. (2011). Quality and Accountability: policy tensions for Australian school leaders. In T. Townsend \& J. Macbeath (Eds.), International Handbook on Leadership for Learning (Vol. 1, pp. 189-208). Dordrecht, The Netherlands: Springer.

Vincent, C., \& Ball, S. J. (2007). “Making Up' " the Middle-Class Child: Families, Activities and Class Dispositions. Sociology, 41(6), 1061-1077.

Vincent, C., Ball, S. J., \& Braun, A. (2010). Between the estate and the state: struggling to be "good" mother. British Journal of Sociology of Education, 31(2), 123-138. 
Appendix 1: Transcription Conventions (based on conventions devised by Gail Jefferson, as used by Atkinson \& Heritage, 1984, ix - xvi).

$=\quad$ latched turns (no intervening pause)

[ heard as interruption or overlap

: $\quad$ extended vowel or consonant

(1.0) approximate pause in seconds

.5 second pause

pause of less than .5 seconds

(( )) transcriber's description

( ) untranscribable

(school) uncertain transcription

$\mathrm{h}$, hh aspirant sound

loud emphasis

MUST reading from text

! exclamatory intonation

? $\quad$ interrogative or upward intonation

... beginning or continuation of talk omitted

so-he-is words said very quickly; words running into each other 